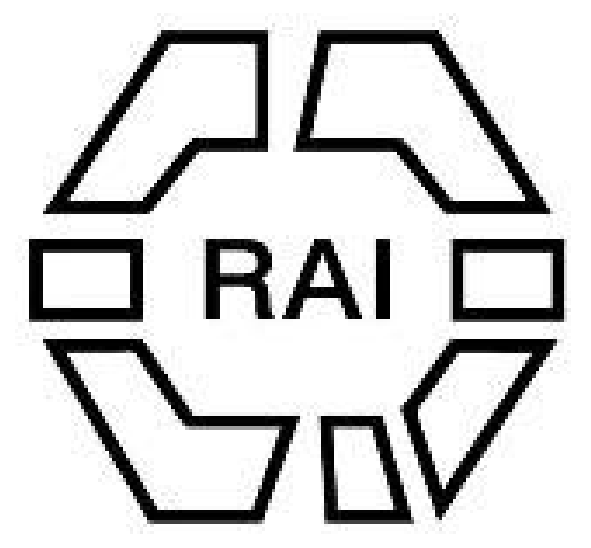

\title{
WILEY
}

2. The Origin of Marriage Prohibition; a Reply to Mr. Lang Author(s): N. W. Thomas

Source: Man, Vol. 4 (1904), pp. 7-9

Published by: Royal Anthropological Institute of Great Britain and Ireland

Stable URL: http://www.jstor.org/stable/2840316

Accessed: 25-06-2016 15:17 UTC

Your use of the JSTOR archive indicates your acceptance of the Terms \& Conditions of Use, available at

http://about.jstor.org/terms

JSTOR is a not-for-profit service that helps scholars, researchers, and students discover, use, and build upon a wide range of content in a trusted digital archive. We use information technology and tools to increase productivity and facilitate new forms of scholarship. For more information about JSTOR, please contact support@jstor.org.

Royal Anthropological Institute of Great Britain and Ireland, Wiley are collaborating with JSTOR to digitize, preserve and extend access to Man 
that the megalithic remains of Rapa Nui, as well as its system of writing, are products of Polynesian culture. The very remoteness of the island may have coutributed, before the period of decadence set in, both to the peculiarity and the excellence of its monuments. Exceptional though it is, this beneficent influence of isolation is not unprecedented. Those parts of prehistoric Europe which, like Eastern Hungary and Scandinavia, were never in the main stream of traffic and intercourse, were left at leisure to develope a bronze civilisation infinitely superior to that of their less isolated neighbours. This superiority we explain by the operation of normal causes without invoking the deus ex machinâ of an alien teacher. May not the course of events have been somewhat similar in this far corner of the Pacific Ocean?

O. M. DALTON.

\section{Marriage Prohibitions.}

Thomas.

The Origin of Marriage Prohibition; a reply to Mr. Lang (MAN, 1903. 101). By N.W. Thomas, M.A.

Mr. Lang's theory in its revised form postulates the following steps: (1) The exogamous local group ; (2) accepts animal names imposed from without ; (3) becomes consciously heterogeneous, distinguishing imported women by means of their tatu marks ; (4) retains the original group-name of such women and applies it to their children; (5) elevates to the dignity of totems the animals from which these intragroupal names are derived; (6) regards people of the same totem as akin; and (7) extends the rule of exogamy, originally due to sexual jealousy, and develops the idea that marriage within the kin is wrong.

At some time during this process, through the adoption by two local groups of preferential customs in respect of eligible spinsters, the phratry organisation grew up. With the rise of kinship bars to marriage members of one connubial group found their choice still further limited to women of the other groups not of their own totem. This complication was too much for the savage brain (to-day capable of working still more complicated rules), and to simplify matters it was agreed to rearrange the totems or rather the kins, hitherto, we may suppose, distributed with more or less regularity between the two groups, in such a way that each kin belonged only to one phratry. Prior to this rearrangement the two totem-kins named after the connubial groups were, in Australia at least, in some way eliminated and disappeared.

It may be noted that Mr. Lang's scheme would work just as well if the totem kins were developed within the group by some other process than the retention of the old group names, e.g., by the rise of co-operative magical societies. The increase in the size of the group, equally implied by Mr. Lang's theory, which must have preceded the formation of intragroupal organisations, would not improbably in the long run result in its disruption; the intragroupal names might then assume more prominence, especially if there was a tendency for societies of the same name to perform their ceremonies in common. If group exogamy still remained the rule, matters would be much simplified by arranging the totem-kins wholly on one side or the other; for if anything like marriage by capture prevailed the raider might not stay to enquire if the bride belonged to the right group, but would, on Mr. Lang's tatuing hypothesis, have a satisfactory means of distinguishing her totem-kin. The old rule of group exogamy would of course operate in favour of kin exogamy if, as I suppose, magical groups were formed. Mr. Lang's view is open to the following objections :-

(a.) It does not account for the fact that phratric names-e.g., Eaglehawk, croware commonly found over wide areas aud are not distributed in a way that Mr. Lang's "casual" origin could explain.

(b.) Mr. Lang assumes that the animals of the original connubial groups did not become totems, and, consequently, that there were no totem-kins corresponding to the original groups. This can only have taken place if a rule were developed that men of 
the Emu group might not marry women of the Emu kin, and vice versâ. This would involve, however, a new rule of exogamy distinct from both group (local) and kin (totem) bars to marriage. This must bave come about either $(a)$ because the Emu kin were regarded as potentially members of the Emu group (an extension of group exogamy the existence of which it would be hard to prove; or $(b)$ because the Emu group or Emu kin were (legally) kindred, and as such debarred from marrying, an hypothesis similar to that which I attributed to Mr. Lang as the explanation of the rise of totem-kin exogamy and by him repudiated in favour of the view criticised below. In either case, on Mr. Lang's theory two whole kins were debarred from marriage or compelled to change their totems. I do not know which is less improbable.

(c.) Mr. Lang accounts for the rise of intra-kin exogamy (not as I imagined when I wrote my review, on the theory that the marriage of near kin came to be regarded as wrong) by making it a corollary of other totem tabus. Against this view it may be said that the clansman is by no means the equivalent of the totem animal. The latter may not be eat $\in \mathrm{n}$, but endocannibalism is not unknown; again, the totem may often not be looked at, but there is, so far as I know, no similar tabu with regard to the clansman. It seems, therefore, highly problematical if this idea would suffice to bring about the rule that members of the same totem kin may not intermarry. Mr. Lang, when he wrote Social Origins was of the same opinion.

(d.) If the rule of group exogamy was still valid, how (and this tells to some extent against my suggestion also) did the savage, in making the rearrangement of kins in the phratries, come to disregard it? It is clear that if the Bats and Sprats were originally divided between the Emu and Kangaroo phratries, the Emu group Bats were, after their transference, eligible mates for the Emu group Sprats, if the Bats were in one phratry and the Sprats in the other. And yet Mr. Lang tells ns that phratric exogamy is the successor and lineal descendant of group exogamy. Unless he supposed the rule had been previously somewbat relaxed, it is not easy to see how Mr. Lang can postulate such a reversal of it.

(e.) As to the descent of the group-names to the children, I am by no means sure that it was such a natural process as Mr. Lang conceives. Originally birth, or even residence within the group, conferred the group-name we may suppose. It is clearly a somewhat revolutionary proceeding for not only the incomers, but even the children born within the group, to receive a name other than the group-name. The fact that in our own day we speak of "the little Browns" is hardly on all fours. Their name is Brown, but Mr. Lang supposes little savages to have rebaptised " the little Bats," who already had personal names, and thus introduced the practice of giving surnames. 'That seems an unlikely origin, and again I suggest the magical society as a more probable key to the mystery. We must not forget that, so far as personal names are concerned, savage practice is the other way, and the father (and sometimes the mother) take their names from their children and not the other way.

As to non-totemistic peoples with group names derived from animals, I might be tempted to suggest the clau Chattan, who, thanks to a folk etymology, believe themselves to be descended from the cat. Are cat-superstitions specially prevalent among them? But $I$ have a better example to my hand. The Sakais of the Malay Peninsula have five endogamous animal or plant-named groups and numerous sub-groups. If, as Mr. Lang suggests-in auswer to my point that he has not attempted to show the development as distinct from the genesis of totemism-the totemistic superstition was an inevitable consequence of the totem name, Mr. Lang should evidently find here a state of things resembling the legendary state of the Arunta. So far as I know, nothing of the sort exists. I submit that this is hecause the animal name alone is not adequate to evoke totemism (indeed, Mr. Lang tacitly concedes this by agreeing that the local auimal-named yroup did not develop totemism). 
I pointed out in my review that the idea of kinship seems too abstract a motive for the rise of a new law of exogany. In his criticism of my remarks, Mr. Lang seems to think that I was combating the idea that kinship through females was a natural and early development, but this is a misapprehension. It is obviously one thing to know your owu mother (kinship as a fact was, I imagine, what Darwin wrote of, the relationship of mother and child, not tribal or group kinship), and another to believe that all persons who bear your mother's name are your kiudred, simply because they bear her name. Even if the idea of kinship did arise in this way within the totem group (and not, as is perhaps more probable, because all members of the totem group were engaged in the same magical ceremonies and akin to the same animal, and therefore to one another), we are still very far from a prohibition of marriage between members of the kin on account of the idea that they are kin.

One point I omitted to notice in my review I may mention here. Neither Mr. Atkinson nor Mr. Lang, so far as I have observed, have made any mention of the light the former's theories tbrow on Jüngstenrecht.

N. W. THOMAS.

Obituary : Spencer.

Brabrook.

Herbert Spencer: born April 27, 1820; died December 8, 1903. By E. W. Brabrook, C.B., F.S.A.

In the general feeling of regret at the loss of a great thinker which has been expressed throughout the civilised world, the Anthropological Institute has a large share, for the life's work of Herbert Spencer was essentially an anthropological work, and he took occasion more than once to testify his sympathy with anthropological studies. It is true that the bent of his mind, the general condition of his health, and the imperious demands of the wide range of thought he proposed to himself and pursued with so much success, led him to shun rather than to seek the membership of scientific societies, all of which wonld have been proud to enrol him on their lists, and that, in pursuance of this method, he never became a Fellow of the Institute; but he contributed to it on June 22, 1875, an important paper as a guide to its Fellows in the psychological section of the work to be undertaken by them. He gave in it "a glance over the whole " subject of comparative human psychology," which he divided into three portions : (1) The degrees of mental evolution of different human types, generally considered ; (2) Inquiries concerning the relative mental natures of the sexes in each race; (5) The more special mental traits distinguishing different types of men. Under the first division he suggested inquiry into mental mass, mental complexity, rate of mental development, relative plasticity, variability, impulsiveness, and the effect produced by mixture of races. Under the second, the degree of difference between the sexes, the differences in mass and in complexity, the variation of the differences, the causes of the differences, mental modifiability in the two sexes, and the sexual sentiment. Under the third, imitativeness, incuriosity, quality of thought, peculiar aptitudes, specialities of emotional nature, and the altruistic sentiments.

Mr. Spencer showed that such a study must influence profoundly our ideas of political arrangements, rectify our conception of the changes gradually taking place in social structure, conduce to a salutary consciousness of the remote effects produced by institutions upon character, and help to rationalise our perverse methods of education, and so to raise intellectual power and moral nature.

Ten years afterwards Dr. Alexander Bain observed of this paper that "thus to " formulate a scheme of human character is not an easy matter. It presupposes a " careful analysis of the mind, an indication of the fundamental attributes of our mental " nature, and some mode of estimating the degree or amount of these several " attributes." 